\title{
Література
}

1. Еремкин А. И. Система межпредметных связей в высшей школе: [аспект подготовки учителя] / А. И. Еремкин. - Харьков : Высшая школа, изд-во Харьк. гос. ун-та, 1984. -154 c.

2. Кондратюк А. П. Межпредметные связи как проблема комплексного подхода к обучению в педвузе / А. П. Кондратюк // Высшее и среднее педагогическое образование. К. : Высшая школа, 1980. - С. 3-11.

3. Максимова В. Н. Межпредметные связи в процессе обучения / В. Н. Максимова. М. : Просвещение, 1988. - 192 с.

4. Никольский Л. Н. Межпредметные связи на базе блок-схем / Л. Н. Никольский // Весник высшей школы. - 1982. - Вып. 6. - С. 26-28.

5. Розенберг Н. М. Межпредметные связи в средних профтехучилищах / H. М. Розенберг // Межпредметные связи в учебно-познавательной работе среднего профтехучилища. - К. : Высшая школа, 1976. - С. 25-42.

6. Сорокин Н. А. Межпредметные связи в профессиональной подготовке учителя / Н. А. Сорокин // Советская педагогика. - 1983. - № 9. - С. 73-78.

7. Стешенко В. В. Теоретические основы реализации межпредметных связей в учебном процессе / В. В. Стешенко. - Славянск : Изд-во СГПИ, 1995. - 118 с.

Стаття надійшла до редакції 14.05.2012 p.

УДК: 373.5: 371

Н. В. Симонович, acnipaнm,

Рівненський державний гуманітарний університет

\section{ТЕОРЕТИЧНІ ОСНОВИ ІНДИВІДУАЛІЗАЦІЇ ТРУДОВОГО НАВЧАННЯ}

Симонович Н. В. Теоретичні основи індивідуалізачії трудового навчання.

У статті розглянуто сутність індивідуалізації навчання та розкрито теоретичні основи використання індивідуального підходу в трудовому навчанні.

Ключові слова: особистість, індивідуальність, індивідуалізачія навчання, індивідуальний підхід.

Симонович Н. В. Теоретические основы индивидуализации трудового обучения.

В статье рассмотрена суть индивидуализачии обучения и раскрыты теоретические основаны использования индивидуального подхода в трудовом обучении.

Ключевые слова: личность, индивидуальность, индивидуализачия обучения, индивидуальный подход.

Simonovych N. Theoretical bases of individualization of labour training.

In the article essence of individualization of teaching is considered and theoretical bases of the use of individual approach are exposed in the labour training.

Key word: personality, individuality, individualization of teaching, individual approach.

Постановка проблеми. Аналіз соціально-педагогічної ситуації на кінець XX ст. та перспектив її розвитку на початок XXI ст., відображених у Державній національній програмі «Освіта. Україна XXI століття» та Концепції загальної середньої освіти, дозволяє зробити висновок про те, що епоха «великої дидактики», що розпочалася у XVII ст. (Я.А. Коменський), не завершується і в XXI ст.

Особистісно зорієнтована модель навчання, сутнісними ознаками якої $\epsilon$ спрямованість навчально-виховного процесу на взаємодію і плідний розвиток особистості педагога та його учнів на основі рівності у спілкуванні 
та партнерства в навчанні, вимагає глибокого осмислення i розуміння педагогами необхідності побудови нової педагогічної системи на основі принципів індивідуального та диференційованого підходів у навчанні.

Державний стандарт освітньої галузі «Технології» одним із завдань передбачає реалізацію здібностей та інтересів учнів у сфері технологічної діяльності, створення умов для самореалізації, розвитку підприємливості та професійного самовизначення кожного учня на засадах особистісно зорієнтованого, компетентнісного і діяльнісного підходів.

При цьому особистісно зорієнтований підхід до навчання забезпечує розвиток академічних, соціокультурних, соціально-психологічних та інших здібностей учнів.

Освітня галузь «Технології» належить до таких галузей освіти, які можуть забезпечити індивідуальний підхід до учнів 3 позиції змісту навчання, розширити варіативність змісту практичної діяльності учнів.

Переорієнтація освіти на особистість учня зумовлює перегляд ставлення до школяра як об'єкта навчання та виховання. Дитина, щоб розвиватися як особистість, має бути суб'єктом саморозвитку, здатним змінювати своє буття і знаходити свою сутність. Учень, як суб'єкт навчання, має стати реальним і повноправним господарем учіння, суспільного життя і майбутньої професійної діяльності, що повністю усвідомлює всю міру відповідальності за зроблений вибір.

Головним ціннісним орієнтиром сучасного навчання в основній школі стає особистість учня, ii просування в процесі навчально-пізнавальної діяльності шляхом розвитку і формування знань, умінь та навичок.

Сучасний стан школи і педагогіки, їі стратегічні цілі (впровадження особистісно зорієнтованого навчання, державних стандартів освіти) висувають на порядок денний проблему розроблення та впровадження в практику школи методики навчання учнів, зорієнтованої на особистість дитини. Основне завдання вчителя - спілкування, взаєморозуміння з учнями, їх «вивільнення» для творчості.

Мета статті полягає в розкритті теоретичних основ індивідуалізації процесу трудового навчання учнів основної школи.

Виклад основного матеріалу. Індивідуальним у людині називають те особливе, що вирізняє іï з-поміж інших людей, а індивідуальністю - яскраво виражену сукупність ознак, властивих окремій людині, які закладені природою або набуті нею в індивідуальному досвіді. Особливими можуть бути інтелектуальні, вольові, моральні, соціальні та інші риси особистості. До індивідуальних особливостей відноситься своєрідність сприймання, мислення, пам'яті, уяви, інтересів, нахилів, здібностей тощо. Вона значною мірою зумовлює процес засвоєння знань, формування всіх якостей особистості.

Щодо розгляду поняття індивідуальності, то існує два підходи трактування його сутності. Прихильники першого підходу пропонують розглядати індивідуальність як сукупність неповторно своєрідних рис та особливостей людини, що відрізняє іï від інших людей, або сукупність властивостей і особливостей кожної істоти, що відрізняють ії від інших істот 
того ж виду. Прихильники другого підходу індивідуальність розглядають як особистість 3 притаманними тільки їй унікальними своєрідними характеристиками, як певний напрям розвитку особистості, що супроводжується появою нових властивостей унаслідок комплексу причин.

Глибоке знання індивідуальних особливостей учня необхідне для розв'язання двох завдань, взаємопов'язаних між собою:

1) індивідуалізації - підтримки і розвитку одиничного, особливого, своєрідного як потенціалу особистості;

2) соціалізації - адаптації у соціальному середовищі і самореалізації особистості в ньому.

Початок теоретичного рівня розроблення індивідуального підходу до учнів у навчанні пов'язують 3 ім'ям К. Ушинського, який уважав вивчення вікових особливостей учнів головною умовою успішного навчання.

Аналіз психолого-педагогічної літератури свідчить, що прогресивні педагоги минулого розглядали індивідуальний підхід як засіб просування кожного учня до нового рівня розумового розвитку.

Наприкінці 20-х років минулого століття метою індивідуального підходу у вітчизняній школі вважалося зменшення кількості відстаючих і прагнення запобігати затримці розвитку талановитих учнів, а індивідуальний підхід став розглядатися як педагогічний принцип.

Основні думки щодо індивідуально-диференційованого підходу до учнів знайшли свій подальший розвиток у працях А. Луначарського, Н. Крупської, П. Блонського, С. Шацького та інших діячів педагогіки.

Вивченням питань індивідуального підходу до учнів як засобу розвитку їх пізнавальної активності та самостійності, проблемного характеру навчання опыкувалися Д. Вількєєв, А. Кірсанов, М. Махмутов та інші.

Дослідження Є. Рабунського й I. Унт зробили суттєвий внесок у розроблення проблеми індивідуального підходу в процесі самостійної роботи учнів.

Багаточисельні дослідження дидактів і психологів: Ю. Бабанського, П. Гальперіна, В. Давидова, Д. Ельконіна, І. Лернера, М. Махмутова, Н. Тализіної та інших дозволили розглядати проблему індивідуального підходу в навчанні з урахуванням нових напрямів у дидактиці та психології.

Г. Костюк звертав увагу на те, що індивідуальний підхід до учнів у навчальній роботі не має зводитися до пристосування до індивідуальних особливостей. Важливий бік цього підходу має полягати у спрямуванні подальшого розвитку цих особливостей у найбільш сприятливому для учнів напрямку [2].

В. Володько визначив індивідуалізацію, як «сукупність елементів, процесів, тенденцій, які утворюють особливу форму наявних явищ об'єктивного світу, особливий рівень його буття. Це відображення певних закономірностей існування матеріальної дійсності, що має онтологічне i гносеологічне значення» [1].

В. Крутецький поняття «індивідуалізація навчального процесу» 
визначив як «реалізацію принципу індивідуального підходу в навчанні, коли воно орієнтується на індивідуально-психологічні можливості учня, будується з урахуванням цих можливостей» [3].

В. Онищук виокремив три рівні реалізації індивідуалізації навчання:

1. Урахування загальних можливостей на різних етапах як навчання, так і розвитку учня.

2. Диференційований підхід.

3. Індивідуальний підхід.

На всіх вище зазначених рівнях індивідуалізацію навчання науковець пропонує розглядати як «своєрідний комплекс організаційних, дидактичних і методологічних заходів, спрямованих на створення оптимальних умов для навчання і розвитку всіх і кожного, зокрема, відповідно до його актуальних динамічних можливостей» [4].

У дослідженнях М. Ляховицького, С. Ніколаєва, І. Унт індивідуалізація навчання трактується як максимальне наближення процесу навчання до оптимальної моделі, коли кожен учень працює у зручному для нього темпі, манері, що відповідають його загальній підготовці, здібностям, обсягу оперативної пам'яті, рисам характеру та емоційному стану.

Значним внеском у розвиток проблеми індивідуалізації стало наукове дослідження А. Кірсанова, у якому вчений розглядає індивідуальний підхід на особистісно-діяльнісній основі.

Науково обгрунтована концепція С. Рабунського присвячена питанням узагальнення теорії та практики реалізації індивідуального підходу до школярів у навчанні.

У трудовому навчанні питаннями індивідуалізації та диференціації опікувалися Г. Терещук, І. Волощук, Г. Левченко, С. Мірський, О. Прядехо.

Г. Терещук підкреслює, що індивідуальність учня на уроках трудового навчання виявляється не лише в його здібностях, але й в інших властивостях особистості, зокрема, у вибірковому ставленні до того або іншого виду діяльності (об’єкта, знаряддя, процесу, результату праці), тобто в інтересах.

Науковцем розроблено комплекс методів для виявлення індивідуальних особливостей школярів на заняттях трудового навчання, а також типологію учнів (залежно від поєднання домінуючих якостей та особливостей у трудовому навчанні; охарактеризовано підсистеми дій різного рівня складності, що рекомендуються для виконання на заняттях трудового навчання; описано найбільш можливі зміни якостей та особливостей учнів у процесі трудового навчання, а також закономірностей підбору i систематизації дидактичних засобів для регулювання суб'єктивної складності самостійної роботи [6].

В. Поляков, узагальнюючи методичні особливості реалізації принципу індивідуального підходу до учнів у трудовому навчанні, підкреслює, що необхідною умовою в цьому процесі $є$ систематичне й всебічне вивчення вчителем кожного учня. У процесі здійснення індивідуального підходу до учнів науковець рекомендує поєднувати фронтальну й індивідуальну форми навчання; здійснювати організацію самостійних робіт, продуктивної праці, 
використовувати індивідуальні бесіди та консультації, застосовувати методи програмованого навчання, диференціювати завдання для учнів за рівнем складності [5].

Висновки. Отже, узагальнюючи вищесказане, можна зробити висновок, що індивідуалізація трудового навчання відображає спрямованість освітнього процесу на особистість, на інтереси учня, на його нахили. У процесі реалізації підходу акцент робиться на персональні особливості діяльності, на характеристику якостей особистості, iii індивідуальні властивості, тобто беруться до уваги особливості кожного учня.

\section{Література}

1. Володько В. Н. Індивідуалізація та диференціація навчання: понятійнокатегорійний аналіз / В. Н. Володько // Педагогіка і психологія. - 1997. - № 1. - С. 9-18.

2. Костюк Г. С. Навчально-виховний процес і психічний розвиток особистості / Г. С. Костюк. - К. : Рад. школа, 1989. - 608 с.

3. Крутецкий В. А. Психология обучения и воспитания школьников / В. А. Крутецкий. - М. : Просвещение, 1976. - 303 с.

4. Онищук В. А. Дидактика современной школы : [пособ. для учит.] / В. А.Онищук. - К. : Рад. школа, 1987. - 351 с.

5. Поляков В. А. Политехнический принцип в трудовом обучении школьников / В. А. Поляков. - М. : Педагогика, 1977. - 215 с.

6. Терещук Г. В. Индивидуализация трудового обучения: дидактический аспект/ Г. В. Терещук. - М.: Ин-т ПСМ РАО, 1993. - 200 с.

Стаття надійшла до редакції 30.05.2012 р. аспірант,

\section{ФОРМУВАННЯ ФАХОВОЇ КОМПЕТЕНТНОСТІ ТЕХНІКІВ-МЕХАНІКІВ СІЛЬСЬКОГО ГОСПОДАРСТВА У ПРОЦЕСІ ВИВЧЕННЯ ФАХОВИХ ДИСЦИПЛІН}

\footnotetext{
Луговська Е. М. Формування фахової компетентності техніків-механіків сільського господарства у прочесі вивчення фахових дисциплін.

У статті розглянуто поняття «фахова дисиипліна», «фахова компетентність» технікамеханіка сільського господарства; уточнено фахові дисципліни спеціальності «Експлуатація та ремонт машин і обладнання агропромислового виробництвва та їх функиії.

Ключові слова: фахова дисиипліна, фахова компетентність, техніки-механіки сільського господарства.

Луговская Э.М. Формирование специальной компетентности техников-механиков сельского хазяйства в процессе изучения спещииальных дисииплин.

В статье рассматривается понятие «профессиональная дисииплина», «профессиональная компетентность» техника-механика сельского хозяйства; уточнены профессиональные дисциплины специильности «Эксплуатация и ремонт машин и оборудование агропромышленного производства» и их функиии.

Ключевые слова: профессиональная дисииплина, профессиональная компетентность, техники-механики сельского хозяйства.
} 